\title{
Independence + Accountability: Why the Fed Is a Well-Designed Central Bank
}

\author{
Christopher J. Waller
}

\begin{abstract}
In 1913, Congress purposefully created the Federal Reserve as an independent central bank, which created a fundamental tension: how to ensure the Fed remains accountable to the electorate without losing its independence. Over the years, there have been changes in the Fed's structure to improve its independence, credibility, accountability, and transparency. These changes have led to a better institutional design that makes U.S. policy credible and based on sound economic reasoning, as opposed to politics. In times of financial and economic crisis, there is an understandable tendency to reexamine the structure of the Federal Reserve System. A central bank's independence, however, is the key tool to ensure a government will not misuse monetary policy for short-term political reasons. (JEL E52, E58)
\end{abstract}

Federal Reserve Bank of St. Louis Review, September/October 2011, 93(5), pp. 293-301.

T

he Federal Reserve has taken unprecedented actions in the financial markets since the advent of the financial crisis. Noteworthy examples include lending more than $\$ 1.5$ trillion to financial institutions and buying $\$ 1.25$ trillion of mortgage-backed securities to stabilize the economy. The large scale of these interventions has brought intense public scrutiny of the Federal Reserve's powers and institutional structure. In particular, many have questioned why the Fed has the freedom to engage in such actions without the explicit consent from Congress or the president. This freedom from political interference is commonly referred to as "central bank independence."

The focus of this article is to review why Congress made the Federal Reserve independent when it created it in 1913. The article also addresses the fundamental tension that comes with an independent central bank: how to ensure that these policymakers are accountable to the electorate without losing their independence.
The key point to remember is that giving the central bank independence is the best method for governments to tie their own hands and prevent them from misusing monetary policy for short-term political reasons.

\section{THE POWER OF MONEY}

Money is obviously a vital part of an economy because it allows trade to occur more efficiently. Governments have a great power that no one else in the economy has-the ability to print money. Thus, the government can acquire more goods by printing more money, a process known as seigniorage. This power, however, brings with it a dangerous temptation. Imagine that you had this power; just think of what you could do with it! You could live a great life, feed the hungry, and house the homeless. And all of this could be achieved simply by printing more money. This sounds wonderful. How can it be dangerous?

Christopher J. Waller is the director of research at the Federal Reserve Bank of St. Louis. A previous version of this article was published in the Federal Reserve Bank of St. Louis annual report for 2009. The author thanks Hoda El-Ghazaly for research assistance.

(C) 2011, The Federal Reserve Bank of St. Louis. The views expressed in this article are those of the author(s) and do not necessarily reflect the views of the Federal Reserve System, the Board of Governors, or the regional Federal Reserve Banks. Articles may be reprinted, reproduced, published, distributed, displayed, and transmitted in their entirety if copyright notice, author name(s), and full citation are included. Abstracts, synopses, and other derivative works may be made only with prior written permission of the Federal Reserve Bank of St. Louis. 
If the government prints too much money, people who sell things for money raise their prices. (These prices can apply to goods, services, and labor.) This lowers the purchasing power and value of the money being printed. In fact, if the government prints too much money, the money becomes worthless. We have seen many governments give in to this temptation, and the result is a hyperinflation. Hyperinflations were observed in the 20th century in Germany (twice), Hungary, Ecuador, Bolivia, and Peru, with Zimbabwe as the most recent casualty. Such episodes of high inflation can greatly impair the functioning of the economy or collapse it altogether. Thus, having the power to print money brings with it great responsibility to respect that power.

It is important to remember that the temptation to print money is not restricted to lessdeveloped countries. In fact, the United States has suffered from high inflation several times. In pre-revolutionary days, many colonies had the right to print money and fell prey to their own excesses. The Continental Congress did the same during the Revolutionary War. In 1775, it gave the colonies the authority to issue Continental dollars to finance the war. Overissuance and counterfeiting by the British led to such dramatic increases in paper currency that by 1779 , the value of a Continental dollar was $1 / 25$ th of its original value (giving rise to the phrase "not worth a continental"). During the Civil War, the Confederate government also succumbed to the temptation of printing money to buy goods. From 1861 to 1864 , the stock of Confederate dollars increased 10-fold, and prices increased the same. Financing government spending via the printing press also occurred in the 20th century. Shortly after the founding of the Federal Reserve, the U.S. Treasury adopted policies that induced the Fed to monetize government debt. ${ }^{1}$ This led to a spike in U.S. inflation following World War I. These examples show that the U.S. government has a history of resorting to the printing press to pay for government expenditures.

\footnotetext{
1 Monetizing debt means the government borrows money to buy goods and then repays its debt by printing more money. This is equivalent to simply printing money in the first place to buy goods.
}

Most governments have taken steps to discipline themselves and impose restraints on their ability to print money to pay for goods. A timehonored method of restraint was to tie the value of the currency to a commodity such as gold. Because the government did not control gold production, the amount of money it could print was limited by its holdings of gold. Although this restrained the government's ability to create seigniorage, it also unfortunately tied its hands during periods of high demand for currency, such as financial crises (a time in which people wanted to hold the government's currency rather than other assets) or during planting season (a time in which farmers needed cash to pay for seed, etc.). Other problems also occurred: New gold discoveries, such as during the California gold rush, led to an inflow of gold and new currency issue, which caused inflation. Conversely, if the economy grew faster than the supply of gold, then prices of goods and services would fall, leading to deflation. Finally, it is very costly to mine gold simply to hold it in storage to back up pieces of paper money. For these reasons and others, governments began to realize that using a gold standard to control the nation's money supply was too restrictive and costly.

As a result, governments slowly moved to a fiat currency system, one in which the money was not backed by a commodity but rather by the "full faith and credit" of the government. Under such a system, the government promises its citizens that it will discipline itself and not resort to seigniorage to finance government spending. In short, citizens have to trust that the government will do the right thing. But trust can be abused; therefore, the citizenry demanded institutional arrangements that backed up the government's pledge.

That is why most governments took steps to tie their own hands and make themselves credible stewards of their nation's economic interests. It became very clear that if elected government officials had direct control of the money supply, then they could cut taxes and print money to pay for goods to win votes. Consequently, promises by elected officials would not be seen as credible. To achieve credibility and avoid this abuse of 
public power for private gain, the control of the money supply had to be delegated to a nonelected group of individuals. These officials were to run the institution responsible for monetary policy, known as the "central bank."

It has always been important that central bankers be independent of the political process to ensure that they cannot be manipulated by elected officials. However, having such great power means that central bankers have to be accountable to the electorate in some fashion, and accountability requires the central bank to behave in a transparent manner. Thus a well-designed central bank needs to be (i) credible, (ii) independent, (iii) accountable, and (iv) transparent.

\section{CENTRAL BANK INDEPENDENCE AND INFLATION}

A key macroeconomic axiom is that sustained high growth rates of a nation's money stock in excess of its production of goods and services eventually produce high and rising inflation rates. This axiom was nicely phrased by Milton Friedman when he said that "inflation is always and everywhere a monetary phenomenon." Economic history is littered with countries that ran afoul of this axiom. A recent example is Zimbabwe, which saw its annual inflation rate rise from 24,411 percent in 2007 to an estimated 89.7 sextillion percent in mid-November $2008 .^{2}$ That's 89,700,000,000,000,000,000,000 percent.

The willingness of governments to force their central banks to print excessive amounts of money, or put in place policies that lead to higher inflation rates over time, has been termed the "inflation bias" of discretionary monetary policymaking. (See Walsh, 2008.) To minimize this bias, many governments have decided to give their central bank legal independence (CBI). But do countries with independent central banks also have lower inflation? To answer this question properly, it's necessary to calculate country-specific measures of central bank independence. Many economists have constructed measures of CBI from a variety

\footnotetext{
${ }^{2}$ See Hanke and Kwok (2009).
}

of legal indicators, many of which are discussed in this article. In a now famous article that was published in 1993, Alesina and Summers (1993) found that developed countries with high levels of central bank independence also experienced lower average levels of inflation for the period 1955-88. Figure 1 is derived from a figure in their paper, which clearly shows this negative relationship.

More recently, as the top chart in Figure 2 shows, global inflation has slowed sharply since the mid-1990s. However, as the bottom two charts indicate, the rapid descent in global inflation was due primarily to conditions in emerging market and developing countries. In the developed countries, the slowing occurred much earlier, in the early 1980s. There were many reasons for the global decline in inflation since the late 1980s, including stronger commitments to price stability (better monetary policies), higher rates of productivity growth, and the forces of globalization that increased competition and enhanced the flexibility of labor and product markets. (See Rogoff, 2003.) As suggested by Alesina and Summers, increased central bank independence appears to be another key reason for the decline in inflation worldwide. As shown in Table 1, there was a marked increase in central bank independence between the period 1980-89 and 2003.

Although this trend was apparent among developed countries, it was especially apparent among emerging market and developing countries. ${ }^{3}$ Indeed, many of the reforms that enhanced central bank independence occurred during the 1990s and were in response to high rates of inflation. (See Cukierman, 2008.) The movement toward greater central bank independence undoubtedly helps to explain the sharp slowing in inflation in many countries.

There was also an increase in CBI in advanced countries. However, the overall movement from weak and moderate independence to strong independence arose mostly from those countries that joined the European Union and thus became members of the European Central Bank (ECB). Because of the Maastricht Treaty, the ECB is

\footnotetext{
${ }^{3}$ The data are published in Crowe and Meade (2007).
} 


\section{Figure 1}

\section{Central Bank Independence versus Average Inflation}

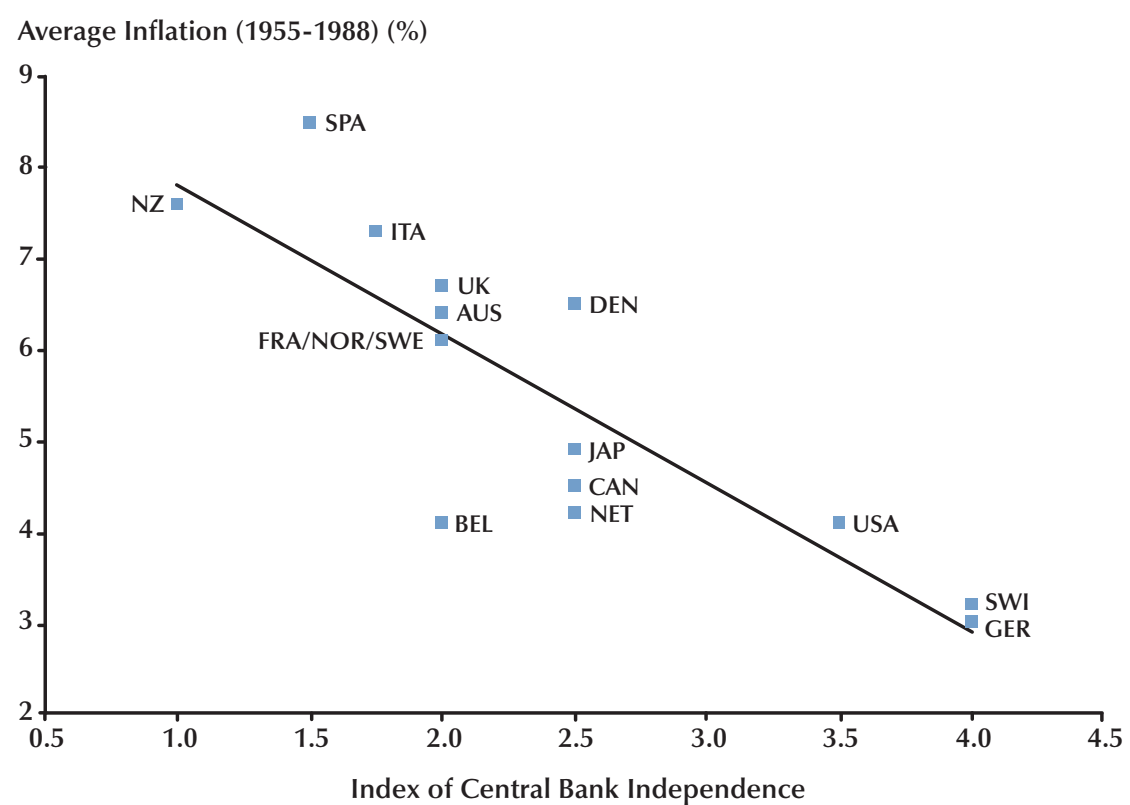

NOTE: Derived from Alesina and Summers (1993).

\section{Table 1}

\section{Measures and Frequency Distribution of Central Bank Independence}

\begin{tabular}{|c|c|c|c|c|c|c|}
\hline & \multicolumn{3}{|c|}{ Developed Economies } & \multicolumn{3}{|c|}{ Emerging \& Developing Economies } \\
\hline & 1980-89 & 2003 & Net Change & $1980-89$ & 2003 & Net Change \\
\hline Weak independence & 13 & 8 & -5 & 32 & 6 & -26 \\
\hline Moderate independence & 8 & 5 & -3 & 19 & 49 & 30 \\
\hline Strong independence & 0 & 13 & 13 & 0 & 15 & 15 \\
\hline
\end{tabular}

NOTE: Crowe and Meade (2007) measure central bank independence on a numerical scale from 0 (no independence) to 1 (complete independence). For this table, weak $\mathrm{CBI}$ is defined to include those banks with a measure from 0 to less than 0.4 ; moderate $\mathrm{CBI}$ is defined as those banks from 0.4 to $\mathbf{0 . 8}$; strong $\mathrm{CBI}$ is for banks with a measure of 0.8 or above. The Federal Reserve's ranking on this scale is 0.47 , and the ECB's ranking is 0.83 . 


\section{Figure 2}

\section{Central Bank Independence versus Average Inflation}

A. World CPI Inflation (\%)

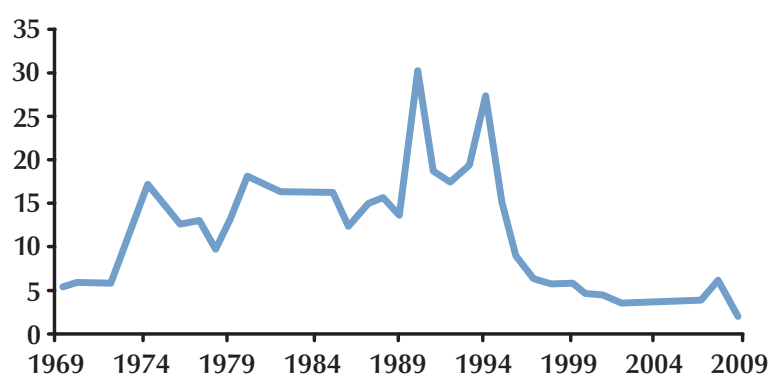

B. CPI Inflation in Developed Economies (\%)



C. CPI Inflation in Emerging and Developing Economies (\%)

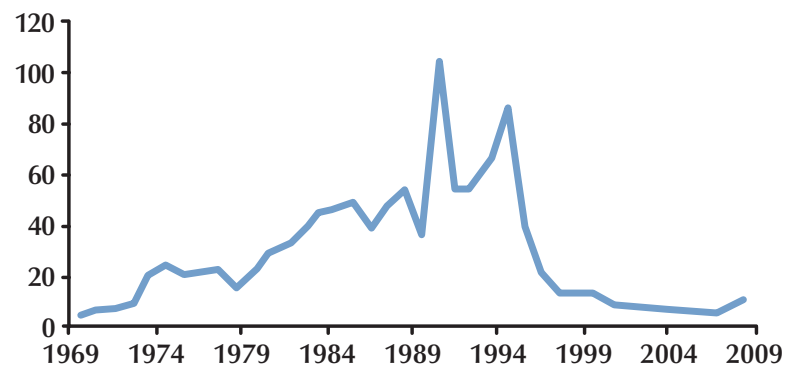

SOURCE: International Monetary Fund. deemed to be strongly independent. Interestingly, while the trend over the past 20 years or so is toward increasing CBI, the Federal Reserve has not become more independent, according to the measure shown in the table. Still, the U.S. inflation rate has slowed markedly since the 1970s and 1980s. This suggests that CBI may be necessary but not sufficient to produce good inflation performance over time-a result that seems to hold for other developed countries as well. However, central bank independence seems to have been much more important for helping to explain the sharp decline in inflation rates since the 1980s for emerging market and developing economies.

\section{A SERIES OF CHECKS AND BALANCES}

The tricky issue is that accountability means being subject to some political oversight, which weakens the perception that the central bank is independent. So, there is an inherent tension between having independence to conduct policy and being accountable to the electorate. Furthermore, if central bankers are not elected, then they must be chosen in another way. But by whom?

In the United States, there has long been a tension between the states and the federal government. States were leery of giving too much power to the federal government out of fear that this power would be abused. Yet, the federal government was the body charged with the welfare of the entire nation. In response to this conflict between the states and the federal government, a series of checks and balances was implemented to ensure that policy was conducted in a way that protected both interests. So, it is not surprising that similar checks and balances would come into play when deciding who selects the nonelected officials to run monetary policy and to whom they would be accountable. Thus, while the Federal Reserve was created to conduct monetary policy, it was given a complicated system of checks and balances to deal with conflicts between the states and the federal government, as well as between the legislative and executive branches of the federal government. 
What are these checks and balances? First, rather than have a single central bank, the founders created a system of central banks. This system includes the Board of Governors in Washington, D.C., and 12 regional Reserve Banks. This arrangement avoided the problem of having strong federal government control of the central bank. The idea behind the regional banks is that the further these policymakers are from the dayto-day political process, the more likely that monetary policy decisions would be made on economic grounds rather than political considerations. Furthermore, the policymakers would be less susceptible to pressures to create seigniorage. The opposite concern is that the regional Banks would focus too much on their own regions (or, in Fed parlance, Federal Reserve Districts). Therefore, the Board of Governors (seven members) was created to ensure that the entire nation's welfare was considered. Thus, policy was to be set by the 12 presidents of the regional Banks (those who served as direct contacts with the states) and the seven members of the Board of Governors (those who were intended to have more of a national view).

Second, who would choose these 19 policymakers? One concern of the founders was that if all of the central bankers were political appointees of the president or Congress, then the Fed would not have the independence it needed to conduct policy in an appropriate manner. It therefore was decided that the presidents of the regional banks would not be political appointees but would be chosen by the citizenry of their Districts in a nonelectoral manner. This ensured that the presidents would be independent of the political process and less likely to engage in seigniorage creation. One method of choosing regional presidents in a nonelectoral manner was to create a local board of directors for each of the 12 regional Reserve Banks. Each board, in turn, would select its regional Bank president. To achieve a broad perspective on the economic well-being of each District, the board was to be composed of individuals from a wide range of sectors. This ensured that the regional Bank presidents would be chosen based on their professional qualifications as opposed to their political connections or sectoral ties.
On the other hand, because 12 of the 19 policymakers were not political appointees, there was concern that there was not enough accountability to the electorate. Thus, it was decided that the seven members of the Board of Governors should be political appointees. The president would have the power to nominate the governors, and the Senate would have the power to confirm them. Consequently, this procedure for selecting the 19 central bankers of the Federal Reserve System provided for both independence and accountability.

Third, a common method for politicians to entice government agencies to carry out specific political agendas is to threaten to cut the agencies' budgets. Thus, no matter how far the presidents of the regional Banks were from Washington, D.C., or how they were chosen, if the Federal Reserve did not have budget autonomy, then Congress could always threaten to cut its budget to get the Fed to carry out monetary policies that Congress desired. This power of the purse strings would undermine the Fed's independence and credibility to keep money creation low and stable. To counteract this possibility, Congress gave the Federal Reserve budget autonomy when it created the Fed in 1913. The Fed was given the power to earn its own income and spend it without government interference. ${ }^{4}$ However, recognizing that the Fed was creating seigniorage for the nation as a whole, Congress directed the Fed to return any excess income to the federal government. To guarantee that excess income was returned, the Fed's income statement and balance sheet had to be transparent and auditable, not by Congress, but by an independent auditing agency to prevent political machinations. Again, checks and balances prevailed.

Fourth, to ensure the credibility of Fed promises to keep money creation under control, Congress created long terms of office for the Board of Governors (14 years) and staggered the governors' terms (one expires every two years). This effectively guaranteed that one president could not appoint all of the members of the Board

\footnotetext{
4 It is interesting to note that, in effect, the members of Congress in 1913 ensured that Congress could not threaten the Fed with budget cuts in the future. Thus, an earlier generation of politicians implemented checks and balances on future generations of congressional representatives.
} 
and therefore "stack" the Fed. Long terms also made the Board more independent of the political process because members did not have to worry about reappointment. Finally, long terms made the Board members more accountable: Policymakers who made promises today would likely still be in office in the future and could be brought to task for failing to live up to earlier promises. As a result, long terms gave current Board members an incentive to carry out promises.

Last, to prevent the Fed from making decisions that benefited a particular industry or region, Congress required the Fed to report on its actions. But to ensure that the Fed maintained its independence, Congress restrained itself from making frequent intrusions. The Fed was therefore required to report regularly to Congress; in return, Congress would not try to influence Fed decisions on a day-to-day or month-to-month basis. This reporting structure again gave the Fed independence, yet made it accountable and transparent to the electorate.

\section{WILL THE FINANCIAL CRISIS FURTHER LIMIT THE FED'S INDEPENDENCE? SHOULD IT?}

The recent recession and financial crisis were, in many respects, the worst since the $1930 \mathrm{~s} .{ }^{5}$ In response, some economists and policymakers have begun to examine the Fed's policies prior to and during the financial crisis to see whether its goals, responsibilities, or institutional structure should be changed to help prevent another financial calamity.

The Federal Reserve Act of 1913 was designed to balance the competing interests of the public and private sectors. Some were afraid of excessive government intervention in private capital markets, while others were worried that the financial sector would have too much influence on the nation's economic well-being. In this spirit, the Act also sought to balance the interests of

\footnotetext{
5 The causes and consequences of the financial crisis have been studied in depth. See the collection of articles and papers listed on the St. Louis Fed's financial crisis timeline at http://timeline.stlouisfed.org/index.cfm?p=articles.
}

Wall Street (financial) and Main Street (business and agriculture). This system, by and large, has served the country well.

Fast forward to 2011. In response to the financial crisis and recession, some people argue that power should be further consolidated in Washington, D.C., to avoid another financial calamity. However, as St. Louis Fed president James Bullard and other Federal Reserve officials and private-sector economists have pointed out, moving the levers of monetary policy even closer to the hub of politics could lead to an erosion of the Fed's independence and, eventually, poor economic performance. ${ }^{6}$

Clearly, part of the desire to subject the Federal Reserve to greater political oversight is natural in a democracy_and may even be a healthy rebalancing to correct misplaced priorities or policies. Few would quibble with the argument that, in a democracy, central banks should be held accountable for their policies. Indeed, if the central bank puts in place policies that run counter to its stated goals, then that will damage the credibility of the central bank. And to a central bank, credibility is something that is valued highly. If a central bank's policies are not credible, then the bank will eventually lose the support of the nation's policymakers-and maybe its independence.

As part of the Fed's accountability to the public, senior Federal Reserve officials testify regularly before Congress. As Figure 3 shows, the number of congressional appearances by Federal Reserve officials has increased significantly over the past few years. This development is probably not too surprising, given the recent financial market turbulence. In addition, appearances by Federal Reserve officials tend to be higher during recessions, as in the early 1980s and the early 1990s. Although part of the increase in congressional appearances over time may reflect a general increase in the number of hearings, it is nonetheless clear that Congress actively scrutinizes the Fed's policies during times of tranquility as well as turmoil. The number of appearances over the

6 See "The Fed at a Crossroads" (http://research.stlouisfed.org/econ/ bullard/BullardWinterInstituteFinal.pdf) by James Bullard, president of the Federal Reserve Bank of St. Louis. 


\section{Figure 3}

\section{Congressional Appearances and Testimonies by Federal Reserve Officials, 1980-2010}

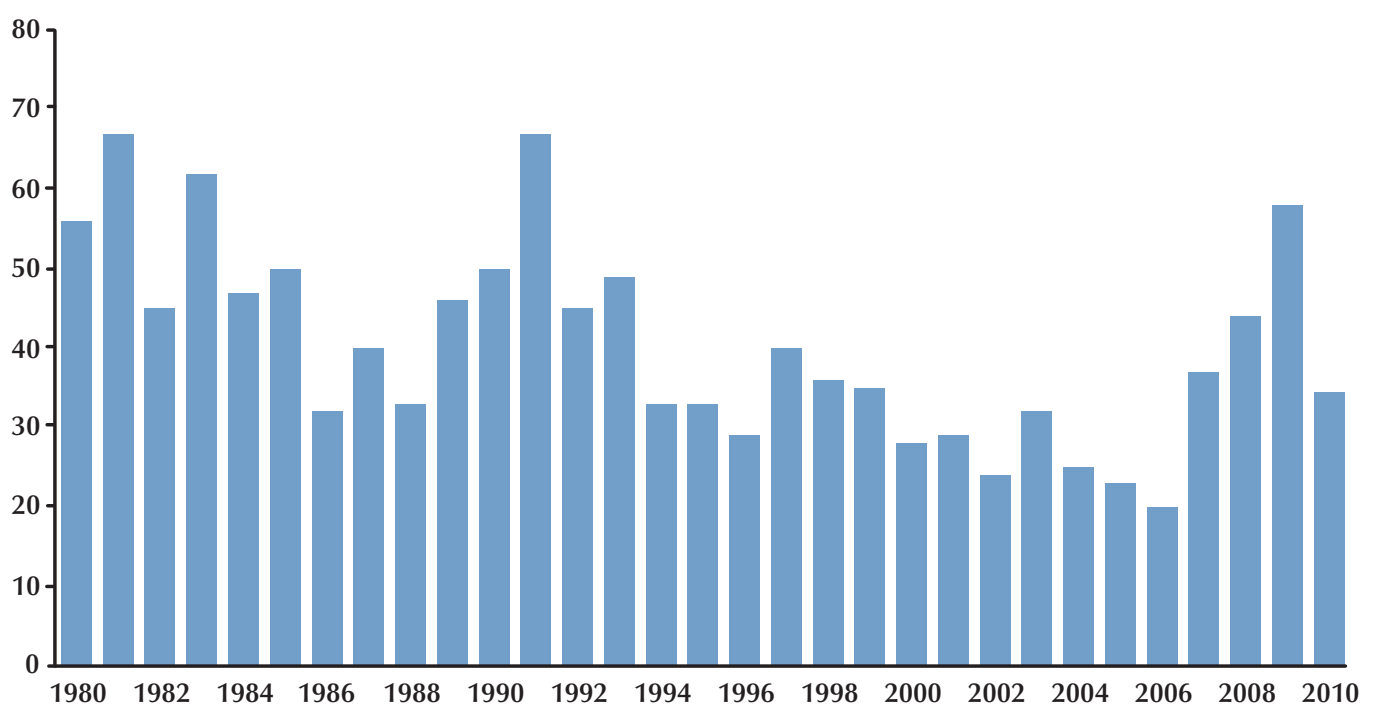

SOURCE: Data compiled by the Federal Reserve Bank of St. Louis using the ProQuest Congressional database.

past four years is on pace to be the largest in about 20 years.

\section{CONCLUSION}

Over the years, there have been changes in the Fed's structure to improve its independence, credibility, accountability, and transparency. These changes have led to a better institutional design that makes U.S. policy credible and based on sound economic reasoning, as opposed to politics. In times of financial and economic crisis, there is a tendency to reexamine the structure of the Federal Reserve System. To the uninformed observer, the Fed's structure is in many ways mind-boggling. In particular, it seems counterintuitive that, in a democracy, the central bank should have independence from Congress. Yet, this independence is the result of Congress trying to avoid making monetary policy mistakes for political gain. Of course, accountability of public policymakers is a fundamental principle in a democracy. It is the tension between independence and accountability that led to the design of the Federal Reserve, and it has been an everpresent force in U.S. monetary policy for the past century.

In the end, the Federal Reserve System is a well-designed institution, created by Congress, that keeps the government from relying on the printing press to finance public spending. It is independent, credible, accountable, and transparent. It is a nearly 100-year-old success story that has served the nation well. 


\section{REFERENCES}

Alesina, Alberto and Summers, Lawrence H. "Central Bank Independence and Macroeconomic Performance: Some Comparative Evidence. " Journal of Money, Credit, and Banking, May 1993, 25(2), pp. 151-62.

Crowe, Christopher and Meade, Ellen E. "The Evolution of Central Bank Governance around the World." Journal of Economic Perspectives, Fall 2007, 21(4), pp. 69-90.

Cukierman, Alex. "Central Bank Independence and Monetary Policymaking Institutions_Past, Present and Future.” European Journal of Political Economy, 2008, 24, pp. 722-36.

Hanke, Steve H. and Kwok, Alex K.F. “On the Measurement of Zimbabwe’s Hyperinflation.” Cato Journal, Spring/Summer 2009, 29(2), pp. 353-64.

Rogoff, Kenneth. "Globalization and Global Disinflation.” Proceedings from the Federal Reserve Bank of Kansas City Economic Symposium, 2003, pp. 77-112.

Walsh, Carl E. "Central Bank Independence.” in Steven N. Durlauf and Lawrence E. Blume, eds., The New Palgrave Dictionary of Economics. Palgrave Macmillan, 2008;

www.dictionaryofeconomics.com/article?id=pde2008 C000081. 
